\title{
Awareness, perceptions and adaptation strategies of women in urban fishing village in a climate change environment - a case study in Versova, Mumbai
}

\author{
BANTI DEBNATH, M. KRISHNAN, P. S. ANANTHAN AND BISWAJIT DEBNATH* \\ ICAR-Central Institute of Fisheries Education, Versova, Andheri West, Mumbai - 400 061, Maharashtra, India \\ *ICAR-Krishi Vigyan Kendra, Birchandra Manu, Manpathar-799 144, Tripura, India \\ e-mail:debnathbanti@gmail.com
}

\begin{abstract}
This study addressed the awareness, perceptions and adaptation strategies undertaken to cope up with the impact of climate change, by the women in Versova urban fishing village, Mumbai in Maharashtra State. Data collection was carried out with the help of a semi-structured interview schedule, from 90 respondents randomly selected from the village. Respondents were from three different groups belonging to fish marketing, casual labourers and homemakers in fishing households. In Versova fisher families, most of the family members are engaged solely in fisheries related activities and they were able to have a feel of the impact of climate change through various sources like mass media. Loss of shelter and declining income from fisheries complemented by unseasonal heat, decrease in rainfall, decline in fish catch and increase in price of fish for last 5 years were the most important impacts of climate change as perceived by them. All respondents reported lack of alternative livelihood opportunities. The findings of the study could help to develop appropriate strategies and policies to mitigate the impact of climate change to make fisheries more viable and sustainable for both fishers and fishing communities.
\end{abstract}

Keywords: Adaptation strategies, Climate change, Fisherwomen, Perception

\section{Introduction}

Rising ocean temperature and green house gases have great influence on fisheries and by default on the fishing communities surviving on fisheries directly or indirectly. The warmer temperature influences the availability, migration pattern, fishing zones and mortality rates of the ocean fish stock which in turn impact the livelihood of coastal fishers. Climate change adversely affect sustainability of fisheries as well as aquaculture leading to an urgent need for alternate livelihood options for the fishing communities. Climate change effect on fisheries also has social and economic impacts to both producers and consumers. Fishing populations depending on fisheries for their livelihood are vulnerable to climate change and hence are forced to adapt and look for alternative livelihood options.

In the coming decades climate change is expected to have considerable effects on the marine environment (Brander, 2007). Not all of these impacts will be negative, but the changes will almost certainly increase the degree of uncertainty (Kristrom, 2002) in terms of temporal and spatial variations of fish populations, habitat viability and stability, as well as ecosystem interactions and feedbacks (Kirby et al, 2009). Climate change is likely to affect fish migrations and habitat, augmenting fish stocks in some places and decreasing them in others, perhaps causing stocks to be displaced permanently to new habitats (Vivekanandan, 2010).
The climate variables viz., enhanced water temperature, extreme events like flood and drought, storms and water stress require specific adaptation actions (Roy, 2012). Adaptation to climate change and variability necessitates the adjustment of a system to moderate the impacts of climate change, to take advantage of new opportunities, and to cope with the consequences (IPCC 2001). Adaptation involves the action that people take in response to projected or actual changes in climate that reduces adverse impacts as well as to take advantage of the opportunities posed by climate change (Parry et al., 2005). Idrisa et al. (2012) stressed the need for strengthening extension education in order to boost farmers' awareness of climate change and to prepare them for adaptation measures.

Climate change is predicted to accentuate the gaps between the worlds' rich and poor, and women are among the poorest and most disadvantaged. Women constitute the majority of the low income earners and are imprisoned in cycle of dependency and co-dependent roles. Women also have to strive to maintain the household and its nutritional needs (Denton, 2000). Women are responsible for feeding their families and therefore are more dependent on nature and natural resources, but their access to these resources is limited. They are also denied full access to loans, education and information (Bathge, 2010). 
Poor social groups bear the brunt of climate change because they are more dependent on natural resources and they also lack the requisite capacity to adapt to climate change. About two thirds of the world's population living in poverty are women, which underlines their greater vulnerability to changing climate. The differential impact of climate change on women and men is due to social norms, traditional roles and different power structures. In developing countries, the mitigation and adaptation are only rarely mentioned in the gender context in general and the empowerment of women in particular (Bathge, 2010). Little has been done so far to address the gender-specific dimension of the climate change issues.

Versova is a fishing village with an exposure of urban society, situated in Mumbai City in Maharashtra along the coast of Arabian Sea. The present population of the village is 25000. There are 1200 households in Versova. Most of the inhabitants of the village are directly or indirectly dependent on fisheries for their livelihood. A large population of Mumbai's fishing community, the kolis, resides at one end of Versova beach. Other than the kolis, a huge number of migrants from Andhra Pradesh, Gujarat, Tamil Nadu and Karnataka do live here and earn their livelihoods, directly or indirectly from fisheries. The present paper focuses on the awareness, perceptions and adaptation strategies of women in Versova fishing village in a climate change environment.

\section{Materials and methods}

The study was conducted in the Versova fishing village in Mumbai following a bottom-up approach. A simple random sampling was done to select 90 respondents purposively which included 30 women involved in fish marketing, 30 women casual labourers and 30 women homemakers from fishing households. A pretested questionnaire was designed to collect the primary data. Secondary data were collected from different sources and mostly from the Versova fishermen societies of the fishing village.

Women involved in fish marketing were selected on the basis of the contribution of income generated from fish marketing as family occupation. Fisherwomen homemakers in fishing households were selected from the families whose family occupation was fishing or family members were owners of boats or fishing boat crew members (other than the labourers in the boats). Fisherwomen casual labourers comprised those who earned their income from rendering casual labour in urban construction sites in Mumbai.

Scoring and ranking method was adopted to obtain responses. Sixteen parameters were identified based on preliminary discussion with the fisherwomen. These preferences were then ranked and scored to indicate the perception of fisherwomen in the various categories in respect of the extent, severity, importance and frequency of the impact of climate change. Similarly 6 parameters were identified to assess the adaptation strategies used by the women to mitigate the effect of climate change. These parameters were assessed across three categories of fisherwomen in terms of the strength of agreement from strongly agree to strongly disagree. Simple percentage analysis and test of significance was done with the help of ANOVA to compare the perception about adaptation strategies between the women in different groups.

\section{Results and discussion}

\section{Intensity of problems and issues}

The study revealed that majority of the women fish sellers and women casual labourers were from marginal and small income groups respectively. However fisherwomen homemakers were from higher income group. These households belong to the 'koli' community who constitute higher income groups of the village. The non-koli population in the Versova Village were people who migrated here decades back. The koli population practice fishing as a traditional occupation and wield both financial as well as enjoy socio-cultural unity and strength. The importance of the sea in the lives of these fisher households as well as frequent weather upheavals, especially during monsoon season has led to increase in certain rituals like 'Narial-poornima' to worship the 'Sea Goddess' before entering the sea for fishing.

Versova suffers from severe sea erosion which has increased significantly of late. The houses of fishers in Versova fishing village is located on the basis of the power hierarchy. The more powerful occupy the inland areas of the beach and the poorest and the least powerful are practically on the high tide line. Due to the rise in sea water level, the poorest group of the villagers who reside adjacent to the shore lose their homes during monsoon season.

It was observed that during the monsoon ban period, $100 \%$ of the respondents do not have any alternative livelihood opportunity. They simply live on their meager savings. The migrants from different parts of the country (Andhra Pradesh, Gujarat, Tamil Nadu and Karnataka) who are involved in fisheries activities move to their native places during the monsoon ban period, but many of them also do not get that opportunity because of social issues in their native places.

\section{Socio-economic profile of the respondents}

The socio-economic profile of the respondents is presented in Table 1. Eighty percent of the respondents from all the three categories of respondents (fisherwomen in fish marketing, fisherwomen casual labour and fisherwomen homemakers in fishing households) were 
Table 1. Basic information on women fishers in Versova fishing village

\begin{tabular}{|c|c|c|c|c|c|c|}
\hline \multirow{2}{*}{ Age group (in years) } & \multicolumn{2}{|c|}{ Women in marketing $(\mathrm{N}=30)$} & \multicolumn{2}{|c|}{ Women casual labour $(\mathrm{N}=30)$} & \multicolumn{2}{|c|}{ Women in fishing households $(\mathrm{N}=30)$} \\
\hline & Frequency & $\%$ & Frequency & $\%$ & Frequency & $\%$ \\
\hline $10-25$ & 2 & 6.7 & 2 & 6.7 & 1 & 3.3 \\
\hline $26-50$ & 24 & 80.0 & 24 & 80.0 & 24 & 80.0 \\
\hline$>50$ & 4 & 13.3 & 4 & 13.3 & 5 & 16.7 \\
\hline \multicolumn{7}{|l|}{ Family members } \\
\hline $1-4 n$ & 12 & 40.0 & 15 & 50.0 & 5 & 16.7 \\
\hline $5-8 n$ & 18 & 60.0 & 13 & 43.3 & 20 & 66.7 \\
\hline$\geq 9 \mathrm{n}$ & 0 & 0 & 2 & 6.7 & 5 & 16.7 \\
\hline \multicolumn{7}{|l|}{ Education } \\
\hline Illiterate & 11 & 36.7 & 20 & 66.7 & 9 & 30 \\
\hline Upto $5^{\text {th }}$ std & 19 & 63.3 & 10 & 33.3 & 16 & 53.3 \\
\hline $6^{\text {th }}-10^{\text {th }}$ std & 0 & 0 & 0 & 0 & 5 & 16.7 \\
\hline \multicolumn{7}{|l|}{ Family occupation } \\
\hline Fishing (Fisherman) & 0 & 0 & 0 & 0 & 0 & 0 \\
\hline Casual labourer & 0 & 0 & 30 & 100 & 0 & 0 \\
\hline Marketing & 12 & 40 & 0 & 0 & 0 & 0 \\
\hline Boat owner & 0 & 0 & 0 & 0 & 30 & 100 \\
\hline Net making & 6 & 20 & 0 & 0 & 0 & 0 \\
\hline Service & 5 & 16.7 & 0 & 0 & 0 & 0 \\
\hline Crew member in boat & 7 & 23.3 & 0 & 0 & 0 & 0 \\
\hline $\begin{array}{l}\text { Alternative livelihood } \\
\text { opportunity }\end{array}$ & NIL & NIL & NIL & NIL & NIL & NIL \\
\hline
\end{tabular}

found to be in the 26-50 years age group, which indicated that women in middle age group are more engaged in fisheries related activities. Sixty three percent of the fisherwomen in fish marketing had education up to $5^{\text {th }}$ standard followed by $37 \%$ illiterate, whereas $66.7 \%$ of the fisherwomen casual labours were found to be illiterate. Among the fisherwomen homemakers in fishing households, $53.3 \%$ were educated up to $5^{\text {th }}$ standard followed by $30 \%$ illiterate and $16.7 \%$ with education up to $10^{\text {th }}$ standard. This shows that fisherwomen homemakers in fishing households were more literate, followed by the fisherwomen in fish marketing, and the casual labour group do not get enough opportunity for education.

Table 2 shows the contribution of women in the total family income from fishery related activities. The fisherwomen casual labourers contribute highest (58.72\%) to their total family income, followed by the fisherwomen in fish marketing (51.48\%) and fisherwomen homemakers in fishing households $(13.89 \%)$. This indicates that in case of women in marketing and women casual labourers, their families are more or less dependent on the women stakeholders' income.

\section{Climate change awareness and perception}

Table 3 shows the extent of awareness on climate change among the respondents in Versova fishing village. The studies revealed that very few of the respondents in each group were aware about climate change, though they were aware about the events related to climate change. Among the respondents, $93.3 \%$ of fisherwomen in fish marketing, $56.7 \%$ of the fisherwomen casual labourers and $96.7 \%$ of the fisherwomen homemakers in fishing households were aware of the impact of climate change events on fisheries and $100 \%$ of the respondents in each group had negative perception about climate change. Most of them hardly find any difference in species composition, though $100 \%$ of them agreed with the decline in fish catch

Table 4, 5 and 6 show the perception of fisherwomen in different groups about climate change and its impact on fisheries and their lives. Table 4 indicates that hot season, decreased rainfall, decline in catch, increase in price for the same quantity of fish for last five years and decrease in amount of fish for auction as the most important visible impacts of

Table 2. Contribution of respondents in the total family income

\begin{tabular}{llll}
\hline Respondent category & $\begin{array}{l}\text { Average family income } \\
(₹)(\mathrm{N}=30)\end{array}$ & $\begin{array}{l}\text { Respondent's income } \\
\text { from fisheries (₹) }\end{array}$ \\
\hline Fisherwomen in fish marketing & 8750 & 3900 & 51.48 \\
Fisherwomen casual labourers & 5700 & 2833 & 58.72 \\
Fisherwomen homemakers in fishing households & 205916 & 20750 & 13.89 \\
\hline
\end{tabular}


Table 3. Women respondents' awareness of climate change in Versova

\begin{tabular}{|c|c|c|c|c|c|c|c|c|c|}
\hline \multirow{2}{*}{ Criteria/problem } & \multicolumn{3}{|c|}{$\begin{array}{l}\text { Fisherwomen in fish marketing } \\
(\mathrm{N}=30)\end{array}$} & \multicolumn{3}{|c|}{$\begin{array}{l}\text { Fisherwomen casual labourers } \\
(\mathrm{N}=30)\end{array}$} & \multicolumn{3}{|c|}{$\begin{array}{l}\text { Fisherwomen homemakers in } \\
\text { fisher households }(\mathrm{N}=30)\end{array}$} \\
\hline & High & Average & Low & High & Average & Low & High & Average & Low \\
\hline $\begin{array}{l}\text { Occurrences of events of climate } \\
\text { change }\end{array}$ & $30(100)$ & $0(0)$ & $0(0)$ & $30(100)$ & $0(0)$ & $0(0)$ & $30(100)$ & $0(0)$ & $0(0)$ \\
\hline Knowledge of climate change & $0(0)$ & $10(33.3)$ & $20(66.7)$ & $0(0)$ & $5(16.66)$ & $25(83.3)$ & $2(6.7)$ & $10(30)$ & $18(60)$ \\
\hline $\begin{array}{l}\text { Impact of climate change on } \\
\text { fisheries }\end{array}$ & $28(93.33)$ & $2(6.66)$ & $0(0)$ & $17(56.66)$ & $10(30)$ & $3(10)$ & $29(96.7)$ & $1(3.33)$ & $0(0)$ \\
\hline $\begin{array}{l}\text { Negative perception of climate } \\
\text { change }\end{array}$ & $30(100)$ & $0(0)$ & $0(0)$ & $30(100)$ & $0(0)$ & $0(0)$ & $30(100)$ & $0(0)$ & $0(0)$ \\
\hline Change in species composition & $2(6.7)$ & $6(20)$ & $23(76.7)$ & $0(0)$ & $7(23.3)$ & $23(76.7)$ & $0(0)$ & $3(10)$ & $27(90)$ \\
\hline Decrease in fish catch & $30(100)$ & $0(0)$ & $0(0)$ & $30(100)$ & $0(0)$ & $0(0)$ & $30(100)$ & $0(0)$ & $0(0)$ \\
\hline Decrease in size of fish in catch & $15(50)$ & $10(30)$ & $5(16.7)$ & $20(66.7)$ & $7(23.3)$ & $3(10)$ & $20(66.7)$ & $7(23.3)$ & $3(10)$ \\
\hline
\end{tabular}

Values in parenthesis are percentage total

Table 4. Perception of fisherwomen in fish marketing about climate change and its impact

\begin{tabular}{|c|c|c|c|c|c|c|}
\hline \multirow{2}{*}{ Climate change and its impact on fishers } & \multicolumn{4}{|c|}{ Perception of fisherwomen in fish marketing } & \multirow{2}{*}{ Score } & \multirow{2}{*}{ Rank } \\
\hline & Extent & Severity & Importance & Frequency & & \\
\hline Rise in ocean temperature & $*$ & $*$ & $*$ & $*$ & 4 & 8 \\
\hline Occurrence of flood & $*$ & $*$ & $* *$ & $* *$ & 6 & $6 \mathrm{~A}$ \\
\hline Occurrence of storm & $*$ & $*$ & $*$ & $*$ & 4 & 8 \\
\hline Hot season & $* * * * *$ & $* * * * *$ & $* * * * *$ & $* * * * *$ & 20 & $1 \mathrm{~A}$ \\
\hline Decrease in rainfall & $* * * * *$ & $* * * * *$ & $* * * * *$ & $* * * * *$ & 20 & $1 \mathrm{~B}$ \\
\hline Depletion of stock & $*$ & $*$ & $* * *$ & $*$ & 6 & $6 \mathrm{~B}$ \\
\hline Deterioration of water quality & $* *$ & $* *$ & $* * *$ & $*$ & 8 & 4 \\
\hline Decline in catch & $* * * * *$ & $* * * * *$ & $* * * * *$ & $* * * * *$ & 20 & $1 \mathrm{C}$ \\
\hline Decline in productivity & $*$ & $*$ & $* *$ & $*$ & 5 & 7 \\
\hline Occurrence of disease & $* *$ & $* *$ & $* * *$ & $* * *$ & 10 & $3 \mathrm{~A}$ \\
\hline Depletion of mangrove area & $* *$ & $* *$ & $* * * *$ & $* *$ & 10 & $3 \mathrm{~B}$ \\
\hline Change in location of fish availability & $*$ & $*$ & $* * *$ & $* *$ & 7 & 5 \\
\hline Pollution & $* * * *$ & $* * *$ & $* * * *$ & $* * * *$ & 15 & 2 \\
\hline Ecological effect & $*$ & $*$ & $*$ & * & 4 & 8 \\
\hline $\begin{array}{l}\text { Increase in price for the same weight of fish for last } \\
5 \text { years }\end{array}$ & $* * * * *$ & $* * * * *$ & $* * * * *$ & $* * * * *$ & 20 & $1 \mathrm{D}$ \\
\hline Decrease in amount of fish for auction & $* * * * *$ & $* * * * *$ & $* * * * *$ & $* * * * *$ & 20 & $1 \mathrm{E}$ \\
\hline
\end{tabular}

More number of * means more importance, A, B, C, D, E - denote equal ranking of different criteria

climate change as perceived by the women in fish markets. Pollution ranked second as the most threatening criteria.

Table 5 shows the perception of fisherwomen casual labourers about climate change and its impact on their lives. Hot season, decreased rainfall, decline in catch, occurrence of disease, pollution, falling income and decreased work opportunity were the most important visible impacts of climate change as perceived by the women casual labourers. Depletion of mangrove area ranked second, the loss of which they felt deeply since it was one of the most important and productive areas which could provide alternative livelihood option to them.

Table 6 shows the perception of fisherwomen homemakers in fishers' households about climate change and its impact on their lives. Hot season, decreased rainfall, decline in catch and increase in price for the same quantity of fish for last 5 years were the most important visible impacts of climate change as perceived by these women in fishing households.

Table 7 shows the adaptation strategies to mitigate the effect of climate change on Versova fishing village as perceived by the fisherwomen.

All fisherwomen strongly agree on availing insurance schemes as a means to monetarily safeguard against the impact of climate change. Ninety percent of the fisherwomen homemakers in fishing households strongly agree with adoption of improved craft and gear as an adaptation strategy, while only $53 \%$ of fisherwomen in fish marketing and $77 \%$ of fisherwomen casual labourers agree with this strategy. Seventy percent of the women in fish marketing and $67 \%$ 
Table 5. Perception of fisherwomen casual labourers about climate change and its impact

\begin{tabular}{|c|c|c|c|c|c|c|}
\hline \multirow{2}{*}{ Climate change and its impact on fishers } & \multicolumn{4}{|c|}{ Perception of women casual labourers } & \multirow[t]{2}{*}{ Score } & \multirow[t]{2}{*}{ Rank } \\
\hline & Extent & Severity & Importance & Frequency & & \\
\hline Rise in ocean temperature & $*$ & $*$ & $*$ & $*$ & 4 & $6 \mathrm{~A}$ \\
\hline Occurrence of flood & $* * *$ & $* * *$ & $* * *$ & $* * *$ & 12 & 3 \\
\hline Occurrence of storm & $*$ & $*$ & $*$ & $*$ & 4 & $6 \mathrm{~B}$ \\
\hline Hot season & $* * * * *$ & $* * * * *$ & $* * * * *$ & $* * * * *$ & 20 & $1 \mathrm{~A}$ \\
\hline Decrease in rainfall & $* * * * *$ & $* * * * *$ & $* * * * *$ & $* * * * *$ & 20 & $1 \mathrm{~B}$ \\
\hline Depletion of stock & $* * *$ & $* *$ & $* * * *$ & $* *$ & 11 & 4 \\
\hline Deterioration of water quality & $* * * * *$ & $* * * * *$ & $* * * * *$ & $* * * * *$ & 8 & $5 \mathrm{~A}$ \\
\hline Decline in catch & $* * * * *$ & $* * * * *$ & $* * * * *$ & $* * * * *$ & 20 & $1 \mathrm{C}$ \\
\hline Decline in productivity & $*$ & $*$ & $*$ & $*$ & 4 & $6 \mathrm{C}$ \\
\hline Occurrence of disease & $* * * * *$ & $* * * * *$ & $* * * * *$ & $* * * * *$ & 20 & $1 \mathrm{D}$ \\
\hline Depletion of mangrove area & $* * *$ & $* * *$ & $* * * *$ & $* * * *$ & 14 & 2 \\
\hline Change in location of fish availability & $* *$ & $* *$ & $* *$ & $* *$ & 8 & $5 \mathrm{~B}$ \\
\hline Pollution & $* * * * *$ & $* * * * *$ & $* * * * *$ & $* * * * *$ & 20 & $1 \mathrm{E}$ \\
\hline Ecological effect & $*$ & $*$ & $*$ & $*$ & 4 & $6 \mathrm{D}$ \\
\hline Fall in income & $* * * * *$ & $* * * * *$ & $* * * * *$ & $* * * * *$ & 20 & $1 \mathrm{~F}$ \\
\hline Decrease in work opportunity & $* * * * *$ & $* * * * *$ & $* * * * *$ & $* * * * *$ & 20 & $1 \mathrm{G}$ \\
\hline
\end{tabular}

More number of * means more importance, A,B,C, D, E, F - denote equal ranking of different criteria

Table 6. Perception of fisherwomen homemakers in fishers' households about climate change and its impact

\begin{tabular}{|c|c|c|c|c|c|c|}
\hline \multirow{2}{*}{ Climate change and its impact on fishers } & \multicolumn{4}{|c|}{ Perception of women in household } & \multirow[t]{2}{*}{ Score } & \multirow[t]{2}{*}{ Rank } \\
\hline & Extent & Severity & Importance & Frequency & & \\
\hline Rise in ocean temperature & * & $*$ & $* *$ & $* *$ & 6 & 7 \\
\hline Occurrence of flood & * & * & * & * & 4 & $8 \mathrm{~A}$ \\
\hline Occurrence of storm & $*$ & $*$ & $*$ & $*$ & 4 & $8 \mathrm{~B}$ \\
\hline Hot season & $* * * * *$ & $* * * * *$ & $* * * * *$ & $* * * * *$ & 20 & $1 \mathrm{~A}$ \\
\hline Decrease in rainfall & $* * * * *$ & $* * * * *$ & $* * * * *$ & $* * * * *$ & 20 & 1B \\
\hline Depletion of stock & $* * * * *$ & $* * * *$ & $* * * * *$ & $* * *$ & 17 & 3 \\
\hline Deterioration of water quality & $* *$ & $* * *$ & $* * * *$ & $* * *$ & 12 & $6 \mathrm{~A}$ \\
\hline Decline in catch & $* * * * *$ & $* * * * *$ & $* * * * *$ & $* * * * *$ & 20 & $1 \mathrm{C}$ \\
\hline Decline in productivity & $* * *$ & $* * *$ & $* * *$ & $* * *$ & 12 & $6 \mathrm{~B}$ \\
\hline Occurrence of disease & $*$ & $*$ & $*$ & $*$ & 4 & $8 \mathrm{C}$ \\
\hline Depletion of mangrove area & $* * * * *$ & $* * * * *$ & $* * * * *$ & $* * * * *$ & 16 & 4 \\
\hline Change in location of fish availability & $* * *$ & $* *$ & $* * * *$ & $* * * *$ & 13 & 5 \\
\hline Pollution & $* * * * *$ & $* * * *$ & $* * * *$ & $* * * * *$ & 18 & $2 \mathrm{~A}$ \\
\hline Ecological effect & * & $*$ & * & * & 4 & $8 \mathrm{D}$ \\
\hline $\begin{array}{l}\text { Increase in price for the same weight of fish for } \\
\text { last } 5 \text { years }\end{array}$ & $* * * * *$ & $* * * * *$ & $* * * * *$ & $* * * * *$ & 20 & $1 \mathrm{D}$ \\
\hline Decrease in amount of fish for auction & $* * * *$ & $* * * *$ & $* * * * *$ & $* * * * *$ & 18 & $2 \mathrm{~B}$ \\
\hline
\end{tabular}

More number of * means more importance, A,B,C, D - denote equal ranking of different criteria

of the fisherwomen homemakers in fishing households feel that conservation of natural resource is necessary. Thirtythree percent of the fisherwomen in fish marketing agree with the community based fishing practice whereas very few fisherwomen casual labourers (17\%) and fisherwomen homemakers in fishing households $(3 \%)$ find community based fishing as an important option. All members of each group found government initiatives and the role of credit institutions as a very important adaptation strategy to survive in a climate change environment. Members of all three groups did not have any other kind of alternative livelihood opportunities and therefore they sought alternative livelihood options. Results of ANOVA showed that the perception about the adaptation strategies across the groups were not significant which indicated that though the respondents gave independent views, they were similar in nature.

The study captures the extent of awareness on climate change, perception as well as adaptation strategies of fisherwomen respondents in Versova fishing village of Mumbai. To a large extent, the women respondents across the three subsectors surveyed, indicated a very high level of awareness about climate change. In addition to the awareness, the clarity of perception of the respondents to parameters 
Table 7. Adaptation strategies to mitigate the effect of climate change in Versova fishing village as perceived by the fisherwomen ( $\mathrm{N}=90)$ (Values in \%)

\begin{tabular}{|c|c|c|c|c|c|c|c|c|c|c|c|c|c|c|c|}
\hline \multirow[t]{2}{*}{ Adaptation strategies } & \multicolumn{5}{|c|}{$\begin{array}{l}\text { Women engaged in fish marketing } \\
(\mathrm{N}=30)\end{array}$} & \multicolumn{5}{|c|}{ Women casual labourers $(\mathrm{N}=30)$} & \multicolumn{5}{|c|}{$\begin{array}{l}\text { Women homemakers in fisher } \\
\text { households }(\mathrm{N}=30)\end{array}$} \\
\hline & SA & A & $\mathrm{NA} / \mathrm{DA}$ & $\mathrm{D}$ & SD & SA & A & $\mathrm{NA} / \mathrm{DA}$ & $\mathrm{D}$ & $\mathrm{SD}$ & SA & A & $\mathrm{NA} / \mathrm{DA}$ & $\mathrm{D}$ & $\mathrm{SD}$ \\
\hline Insurance & - & - & - & - & - & - & & 100 & - & - & 100 & - & - & - & - \\
\hline Improved craft and gear & - & 53 & 47 & - & - & - & 77 & 23 & - & - & 90 & 10 & - & - & - \\
\hline $\begin{array}{l}\text { Conservation of natural } \\
\text { resources }\end{array}$ & - & 70 & 30 & - & - & - & - & 100 & - & - & & 67 & 33 & - & - \\
\hline Community based fishing & - & 33 & 67 & - & - & - & 17 & 83 & - & - & 3 & - & 97 & - & - \\
\hline $\begin{array}{l}\text { Govt. initiative and role of } \\
\text { credit institutions }\end{array}$ & 100 & - & - & - & - & 100 & - & - & - & - & 100 & - & - & - & - \\
\hline $\begin{array}{l}\text { Alternative livelihood } \\
\text { option }\end{array}$ & 100 & - & - & - & - & 100 & - & - & - & - & 100 & - & - & - & - \\
\hline
\end{tabular}

SA-strongly agree, A-Agree, NA/DA-neither agree/disagree, D-Disagree, SD-Strongly disagree

indicating climate change and its impact on fisheries was remarkably clear. The investigators also did not have any difficulty in conveying a list of adaptation strategies to the respondents. The statistical analysis also indicated significant level of awareness, clarity in perception and almost complete understanding of adaptation strategies for mitigating the impact of climate change among the respondents of this study. Therefore, it is safely understood that exposure to mass media, information extended by various Government as well as non-Government institutions operating in Versova fishing village and regular interactions of the villagers with urban public, heightened the awareness of these particular village in respect of impacts of climate change. The results of the study also indicate the indirect positive impact of urban exposure and education of the younger generation on adult family members in these fisher's households.

\section{Acknowledgements}

The authors gratefully acknowledge the encouragement and support from the Director/Vice Chancellor, ICAR-CIFE, Mumbai during the course of this work.

\section{References}

Brander, K. M. 2007. Global fish production and climate change. Proc. Nat. Acad. Sci., 104: 19709-19714.

Bathge, S. 2010. The governance cluster, climate change and gender: economic empowerment of women through climate mitigation and adaptation? Working paper, p. 3-4, http:// www.oecd.org/social/genderequalityanddevelopment.

Debnath Banti 2015. Gender perspectives in fisheries development in India: determinants, adoption behaviour and sustainable livelihoods, Ph. D. thesis, ICAR-Central Institute of Fisheries Education, Mumbai, India, 176 pp.
Debnath Banti, Krishnan, M., Biswajit Debnath, Ananthan, P. S., Arpita Sharma and Rama Sharma 2015. Gender perspectives in adoption of technological practices by fishers and fish farmers in Tripura, Indian J. Fish., 28(1) : 117-125.

Denton, F. 2000. Gendered impacts of climate change - A human security dimension, Energia, 3(3).

Heal, G. and Kristrom, B. 2002. Uncertainty and climate change. Environ. Res. Econ., 22(1-2): 3-9.

Idrisa, Y. L., Ogunbameru, B. O., Ibrahim, A. A. and Bawa, D. B. 2012. Analysis of awareness and adaptation to climate change among farmers in the Sahel savanna agro-ecological zone of Borno State, Nigeria, African J. Agric. Res., 7(25) : 3632-3637.

IPCC 2001. IPCC $3^{r d}$ Assessment Report - Climate Change 2001: Working Group II: Impacts, adaptation and vulnerability. http://www.ipcc.ch/ipccreports/index.htm

Kirby, R. R., Beaugrand, G. and Lindley, A. 2009. Synergistic effects of climate change and fishing in a marine ecosystem, Ecosystems, 12: 548-561.

Parry J, Hammill, A. and Drexhage, J. 2005. Climate change and adaptation. Manitoba, Canada. http://www.iisd.org.

Roy, T. N. 2012. Economic analysis of producers' perception about impact of climate change on fisheries in West Bengal. Agric. Econ .Res. Rev., 25(1): 161-166.

Vivekanandan, E. 2010. Impact and adaptation option for Indian marine fisheries to climate change. In:. Prasada Rao, G.S.L.H.V. (Ed.), Climate change adaptation strategies in agriculture and allied sectors, Scientific Publishers, New Delhi, p.107-117.

Date of Receipt $\quad$ : 23.04.2014

Date of Acceptance : 12.09 .2016 